\title{
The Red-billed Curassow
}

\section{Michael Gochfeld and Stuart Keith}

The red-billed curassow, or mutum, Crax blumbachii formerly occurred from southern Bahia to Rio de Janeiro in south-east Brazil, ${ }^{4,6}$ although only a few specimens were ever obtained. Europeans settled this region early, and it was feared that hunting pressure and, later, habitat destruction had brought the species to the verge of extinction when in 1970 Sick $^{5}$ discovered a population about $60 \mathrm{~km}$ north of Linhares, Espirito Santo, in and near what is now the Reserva de Sooretama. This forest reserve is now the only place where the bird is known. A few may survive in relict forest tracts in southern Bahia, although the last record, a specimen, was collected in $1944 .^{2}$ The specimen from eastern Bolivia which Gyldenstolpe assigned to this species $^{3}$ was certainly a variant of $C$. globulosa. ${ }^{6}$ On a recent trip to Brazil we found that almost all the forest in north-east Espirito Santo, where this curassow formerly occurred, had been cleared, much of it within the year. Dr Augusto Ruschi (pers. comm.) confirms that the rate of forest destruction, mainly for charcoal, has accelerated markedly in the past decade. The main sources for information on the species are Prince Maximilian of Wied ${ }^{1}$ and Sick. ${ }^{5}$

In September 1973 we spent six days at Sooretama; we covered only a small part of the approximately 24,000 hectares of forest and encountered curassows at three places. The main concentration was around the forestry camp on the western edge of the reserve where from one to six birds, which were quite habituated to humans, came morning and evening, often in pairs, to feed with the domestic fowls. Driving on the north perimeter road, near the Rio Barro São Juan, we saw a male Crax feeding on the ground in a small patch of forest; with it were three rusty-margined guans, or jacupemba, Penelope superciliaris which flew noisily up into the trees at our approach, while the curassow galloped back and forth through the undergrowth, until, catching sight of us, it flew up nearly vertically to a branch about four metres above ground; then within seconds, with one 'snorting' alarm call, it flew out of the small woodland and across the road.

One morning about fifteen minutes after sunrise, in cut-over secondgrowth forest, we heard a male Crax singing about eight metres above ground. The bird, which was almost completely concealed in a tangle of leafy vines, began its song with an initial popping note followed by a thin, shrill descending whistle, uttered at intervals of 10-12 seconds. The same song was heard from a caged male at the Museu Prof. Mello Leitão. The curassows also sang in the hours before dawn from their roosting trees around the forest camp, uttering their characteristic deep booming notes. We never saw more than six at the camp, although the forest workers said that a dozen or more are sometimes present, and in 1960 Sick once saw twenty-five. They would break into a trot if approached closely, but their relative tolerance indicates that they are not persecuted by humans.

Nearly always they walked from the forest to the farmyard, but once on the forest edge a male flew up to a perch about seven metres off the ground and remained there for nearly an hour before flying into the forest. Once a 
domestic rooster that was actively courting hens attacked a male curassow that had just arrived to feed on grain, flying up at the face of the larger bird, which turned and trotted off a few metres. No other aggressive encounters were noted.

The Sooretama reserve is now an island surrounded by cultivation. The few other remaining patches of forest in Espirito Santo lowlands are also dwindling and isolated, and outside the refuges hunting pressure on any cracid is probably severe. The Sooretama Reserve is patrolled and permits are required to visit it, but one cannot be complacent about its future. Professor A. Ruschi, Director of the Museu Prof. Mello Leitão, informed me that at one time a state governor contracted with a private concern to have the forest lumbered, and planned to replant it with eucalypts and pines - a widespread forest practice elsewhere in southern Brazil. Only federal government intervention preserved it, and vicissitudes of politics may again jeopardise it. As there is no evidence that this curassow survives anywhere else, preservation of the refuge is critical. On such a brief visit we could not assess the size of the population, but it is probably sufficiently small and isolated for there to be a threat of inbreeding. Furthermore, the relative tameness of some of the birds and their accessibility means that a sizeable part of the population could be eliminated in a few minues of vandalism; it is a tribute to the forest protectors that these have survived so long, particularly since the forest camp is on the very edge of the reserve.

In addition to encouraging the continued protectionist attitude on the reserve and maintaining vigilance against schemes that would diminish its size and security, it is urgent that other forest tracts in Bahia, Espirito Santo and south-eastern Minas Gerais be searched for other populations. Moreover, the lowland forests of south-east Brazil have a sizeable endemic fauna, so that many smaller species are also threatened.

It is worth mentioning that we did not see the black-fronted piping guan, or jacutinga, Aburria (= Pipile) jacutinga anywhere during our visit to southern Brazil, and the forest workers consider it has been extirpated at Sooretama. Ruschi (pers. comm.) verified that it formerly occurred there but was eliminated by hunting, and an attempt to re-establish it failed. Although it ranges widely $^{1}$ over south-east Brazil and northern Argentina, it too may be endangered. By contrast the rusty-margined guan Penelope superciliaris seemed common in several areas, even in small forest tracts.

\section{Literature cited}

1. DELACOUR, J. and AMADON, D., 1973. Curassows and related birds. Amer. Mus. Nat. Hist., N. Y.

2. GREENWAY, J., 1958. Extinct and Vanishing Birds of the World. American Committee for International Wild Life Protection, Special Publication No. 13.

3. GYLDENSTOLPE, N., 1945. A contribution to the ornithology of northern Bolivia. K. svenska Vetensk Akad Handl. 23: 1-300.

4. MEYER DE SCHAUENSEE, R., 1966. The Species of Birds of South America. Livingston Press, Narbeth, Pa.

5. SICK, H., 1970. Notes on Brazilian Cracidae. Condor 72: 106-108.

6. VAURIE, C., 1968. Taxonomy of the Cracidae (Aves) Bull. Am Mus. nat. Hist 138 : 131-260.

Department of Ornithology, American Museum of Natural History, New York 10024, U.S.A. 